\title{
TREND OF GROWTH AND PRODUCTIVITY OF HORTICULTURAL PRODUCTS IN INDIA AND ODISHA
}

\author{
Smruti Rekha Basa ${ }^{1}$, Dr. Kabita Kumari Sahu ${ }^{2}$ \\ ${ }^{1}$ PhD Research Scholar in Economics, MSCB University, Baripada, Mayurbhanj, Odisha \\ ${ }^{2}$ Assistant Professor of Economics, MSCB University, Baripada, Mayurbhanj, Odisha
}

Article DOI: https://doi.org/10.36713/epra6948

DOI No: 10.36713/epra6948

\begin{abstract}
The objective of the study is to analyse the trend, growth and productivity of horticulture crops in India and Odisha. The study is based on secondary data. It is observed that the factors like market scenario, export promotion, suitable climatic condition, and storage facility to avoid damage risk of crops are very crucial. There are lots of factors that affect the growth trend of different horticulture crops. The overall trend is fluctuating over the years. All the crops those are taken in to consideration for the study are in declining trend. There is a need of effective approach to enlarge horticulture sector. The factors like irrigation facility, market condition of the horticultural products, promotion of the crops, storage facility of the crops, training of the farmers and environmental factors such as climate and geographical characteristics such as quality of soil and ground water table influence the horticulture practices as well as other agriculture productivity and export of the products. Moreover, awareness, skill and quality control strategies depreciate the turnover and so as the farmers in India.
\end{abstract}

KEY WORDS: Area, Crop, Growth, Horticulture, Productivity

\section{INTRODUCTION}

India is a land with varied soil and climatology comprising diverse agro-climatic regions provides huge opportunity to grow a huge variety of horticulture crops. These huge variety of crops from a substantial part of total agricultural produce in the country including fruits, vegetables, flowers, tuber crops, roots, ornamental plants, medicinal and aromatic plants, spices, plantation crops, mushrooms and condiments. According to the history of horticulture science horticulture development had not been precedence until recent years. During the 80's the main emphasis was on cereals. But in 90's the developing of horticulture was started. The institutional support and planned process for the development of horticulture had started. Later the post 1993 period more attention was given on the development of horticulture through the efficient allocation of the plan and knowledge-based techniques (KBT).

Though horticulture practices were started earlier period of time (Srinivasan, 1961) but after launching National Horticulture Mission (NHM) in April 2005 the promotion of horticulture have been started by implementing different strategies. The role of Foreign trade policy in 2004-09 is also important to enhance the agricultural exports, growth and promotion of horticultural yields (ICAR Report, 2010). The horticulture sector started growing at an average of 3.6 percent after launching the NHM in 2005 (ICAR Report, 2010) during the period of 2001-02 to 2009-10.

\section{OBJECTIVES}

The main objective of this paper is to show the trend of growth of area and production of horticulture crops in India and Odisha. The study also 
focusses on inter-crop and inter-state comparison of growth of horticultural production.

\section{DATA AND METHODOLOGY}

The present study is based on secondary data. The Secondary data are collected from published sources of Horticulture Division, Department of Agriculture \& Cooperation, Ministry of Agriculture \& Farmers Welfare, Govt of India, Reports of National Horticulture Board, The Directorate of Horticulture, Bhubaneswar, Odisha, Reserve Bank database, and Food Statistics. The growth trend has been analysed with the help of graphical method.

\section{LITERATURE REVIEW}

To understand the growth and productivity as well as the factors that affect horticulture production past literatures have been extensively swotted. According to Patel (2005) the importance and scope of under exploded horticultural crops having lot of potential to grow with less maintenance in North Eastern region, the underutilizing horticulture crop are blessed with many merits and easily tolerate the adverse climate condition, soil structure. According to George et al. (2010) through diversification of crops small and marginal coconut grower improving their food and nutritional security. Suitable intercrop like vegetables, plantation, crops and tubers are major success factors, it accelerated the horticulture growth as well as improve the purchasing power per people. Sati (2018) trying to focus the progress in horticultural farming and undergoing used pattern of cultivation in rural area of Uttarakhand. A huge range of horticultural crops grown in Uttarakhand. Vishnu et al. (2014) argued that recently people are diversified towards horticulture rather than cereal farming. This has been revealed in the different areas of Karnataka. Most of the diversified areas under dry agro climatic zone, the growth rate also high in horticulture crop cultivation whereas less diversified area got less growth rate. The benefit and barriers of organic fertilizer which are the waste product from horticulture itself. As per the study more than $90 \%$ of manners were applied directly to the land. Nabi and Bagalkoti (2017) have identified that the change of customers habit, more employment opportunity, modern technology, urbanization push the farmers towards the horticulture practices in the rural areas. Also, storage facility, use of waste lands can boost the growth rate more. As argued by Kamei (2013) despite having basic transport facility connecting to nearby big cities and huge range of land having potentiality for growing other kind of horticultural crops still it comes under the negligence of the policy makers. According to Pathak et al., (2019) there is a massive diversion seen from the traditional agriculture to the horticultural sector in Madhya Pradesh. The farmers are experiencing the crop damage by irregularity of rain. According to Patra (2014) by making district wise analysis the author has outlined that the district like, Mayurbhanj, Keonjhar, Sundargarh districts have achieved unceasing achievements while rest of the districts are lacking behind except Khordha, Raygada, Koraput, Nabarangapur, Malkangiri and Boudha which are on the way of progress. This would be due to the both regional and agro-climatic inconsistencies.

Singh (2009) has outlined the scenario and influences of export of horticulture products by encompassing a wide range of crops such as fruits, vegetables, tuber, medicinal, aromatic, spices, plantation with diversification of environmental factors. Birthal et al., (2008) have distinguished different demand and supply side factors that enrich the growth and influence the factors for comprehensive agriculture growth. Rupa et al. (2019) have analyzed the need of fertilizer in horticultural crops to boost up the production of the horticultural crops. Gradually they demand for horticultural crop are increasing both for export and domestic consumption many places have deficiency symptoms of various minerals and soil structure also different in every area. To overcome the lacuna appropriate application of fertilizer management is required. According to Bader et al. (2020) irrigation facility is like a blessing for the horticulture. Lack of irrigation facility dishearten the agriculture practices. Drip irrigation helps plants to grow in a better way which directly affect the growth in productivity. Kundu (2018) The export chain can give much better result which will increase the interest of the farmers as well as provide a better livelihood to the farmers. According to Mittal (2007) the main constraints of horticulture marketing quality products are quality of seeds, lack of irrigation, soil examine facilities (Kumar and Pal, 2004), problem in pest management, cost of production, improper postharvest management, shortage of market knowledge about the different products and the transportation facilities. In Odisha the organizations like ORMAS, Kandhamal Apex Association and Marketing (KASAM) are playing a pivotal role to market the agricultural as well as the horticultural products. As discussed by Datta (2013) high temperature and air pollution depreciate the horticultural yields. The horticultural such as apple, saffron, Rhododendron, Orchid, spongy tissue of mango, litchi and floriculture are very much affected by the climate uncertainties. According to Meena et al., (2009) in an underdeveloped region post-harvest issue is a very 


\section{SJIF Impact Factor 2021: 8.013| ISI I.F.Value:1.241| Journal DOI: 10.36713/epra2016 ISSN: 2455-7838(Online) EPRA International Journal of Research and Development (IJRD)}

throbbing for the farmers due to storage and marketing system of the agricultural yields and climate risks. As a consequence, farmers are disheartened by the pull influences. There is a reduction of rice cultivation area due to the climatic hammer (Singh 2018). The agriculture system of Odisha has been affected from the barrage of climate change. As it is the part of semi-arid zone the impact of climate change is a matter-of-fact to think about it.

\section{GROWTH AND PRODUCTIVITY OF HORTICULTURE CROPS IN INDIA}

In Table- 1 state wise growth percentage of horticulture crops has been portrayed for India throughout the period 2001-02 to 2017-18. It has been observed that the growth scenario of horticulture crop in Odisha is not up to the mark over the period with below 10 percent. Only during 201011 has been registered a noteworthy growth with 17.2 percent. Main reason is to lack of focus on horticulture practices in Odisha. Climate is another factor to deteriorate the growth rate of horticulture in Odisha. Market structure is another vigorous factor to deter the horticulture practices. Among the states
Andhra Pradesh, Assam, Gujarat, Madhya Pradesh and Uttar Pradesh have registered a remarkable growth in horticultural, crops practices. The supply side factors like new technology, diversification of value of the crops, increase in price of the crops, area expansion, increasing use of modern seeds, chemical fertilizers and electricity have the combined role to accelerate the cumulative growth of the agriculture productivity. On the other hand, the factors viz., the lethargic growth in inputs, deprivation of soil health, exhausting water table and price policy of the government and credit facility depreciated the productivity of the agriculture sector. "Demand-led growth" in horticulture is supported by pleasing to the eye towards the public infrastructure such as market communication and sound policy implication in the food processing environment. Horticulture crop production has a tremendous impact on agriculture system. The production increases near about 5 times from 5.5 million tons to 54.04 million tones since 2013. Innovative technology, market channels, market behavior modern technologies boost the productivity. Despite this India export only $1.4 \%$ fruit and vegetable in global share.

Table 1: Crop wise percentage growth of horticulture Production in India.

\begin{tabular}{|c|c|c|c|c|c|c|c|c|c|c|c|c|}
\hline \multirow[b]{2}{*}{ Year } & \multicolumn{2}{|c|}{ Fruits } & \multicolumn{2}{|c|}{ Vegetables } & \multicolumn{2}{|c|}{$\begin{array}{c}\text { Flowers, Aromatic \& } \\
\text { Medicinal }\end{array}$} & \multicolumn{2}{|c|}{ Plantation Crops } & \multicolumn{2}{|c|}{ Spices } & \multicolumn{2}{|c|}{ Total } \\
\hline & Area & Production & Area & Production & Area & Production & Area & Production & Area & Production & Area & Production \\
\hline 2001-02 & -5.536 & 5.121 & -1.040 & -4.296 & -33.962 & 37.383 & 0.000 & 0.000 & 0.000 & 0.000 & -1.941 & -0.964 \\
\hline $2002-03$ & 23.046 & 1.635 & -0.164 & 4.149 & 44.286 & -21.088 & 3.954 & 60.093 & 60.093 & 35.803 & 18.058 & 6.180 \\
\hline $2003-04$ & 10.599 & 10.983 & 10.885 & 14.617 & 146.535 & 41.034 & 1.451 & -38.894 & $\begin{array}{c}- \\
38.894 \\
\end{array}$ & -21.748 & -3.972 & 8.896 \\
\hline 2004-05 & 3.278 & 8.567 & 6.954 & 10.028 & 57.028 & 4.645 & 4.290 & -24.889 & $\begin{array}{c}- \\
24.889\end{array}$ & -7.398 & 1.420 & 9.511 \\
\hline 2005-06 & 4.320 & 7.600 & 5.102 & 3.226 & 19.693 & 23.598 & -2.285 & 3.466 & 3.466 & 6.694 & 3.646 & 4.921 \\
\hline $2006-07$ & 5.456 & 10.114 & 3.522 & 11.702 & 20.299 & 19.471 & -0.530 & 6.904 & 6.904 & 10.220 & 4.219 & 10.125 \\
\hline $2007-08$ & 4.166 & 4.390 & 1.695 & 0.489 & 6.039 & 12.104 & 0.846 & 0.459 & 0.459 & -4.866 & 2.252 & 1.648 \\
\hline 2008-09 & 3.737 & 4.455 & 0.050 & 3.611 & 15.913 & 12.421 & 1.492 & -6.276 & -6.276 & -3.112 & 1.036 & 3.993 \\
\hline 2009-10 & 0.853 & 4.701 & 6.387 & 9.583 & 1.301 & 2.699 & 1.256 & 19.318 & 19.318 & 33.217 & 4.546 & 7.722 \\
\hline 2010-11 & 5.045 & 2.065 & 5.815 & 6.667 & 8.417 & 35.575 & 8.197 & 9.252 & 9.252 & 11.234 & 6.497 & 6.962 \\
\hline 2011-12 & 4.131 & 6.361 & 2.403 & 3.750 & 3.947 & 19.342 & 1.789 & -4.234 & -4.234 & -3.478 & 1.940 & 4.497 \\
\hline $2012-13$ & 3.351 & 9.463 & 2.075 & 0.438 & -5.316 & 20.589 & 0.934 & 2.828 & 2.828 & 2.855 & 2.127 & 3.163 \\
\hline $2013-14$ & 15.327 & -2.669 & 1.554 & 4.040 & 21.390 & -1.535 & -3.837 & 4.869 & 4.869 & 3.385 & -3.256 & 1.310 \\
\hline 2014-15 & 3.126 & 4.135 & 5.911 & -0.244 & 0.441 & 2.004 & 4.131 & 4.733 & 4.733 & 14.407 & 4.537 & 1.851 \\
\hline $2015-16$ & 1.143 & 3.033 & 1.306 & 5.387 & 6.360 & 4.928 & -2.228 & 5.671 & 5.671 & 16.228 & 1.549 & 5.051 \\
\hline $2016-17$ & 2.087 & 4.778 & 0.205 & 3.492 & 7.629 & 8.532 & 4.058 & 5.639 & 5.639 & 0.025 & 2.334 & 3.682 \\
\hline 2017-18 & $\begin{array}{c}- \\
66.834\end{array}$ & -85.810 & $\begin{array}{c}- \\
93.594\end{array}$ & -95.152 & -99.367 & -99.318 & $\begin{array}{c}- \\
94.710\end{array}$ & -96.184 & $\begin{array}{c}- \\
96.184\end{array}$ & -93.727 & $\begin{array}{c}- \\
87.544\end{array}$ & -92.486 \\
\hline
\end{tabular}

Sources: Author's calculation from the secondary data

According to Table- 1 and Figure 1 it is clear that the trend of both the area and production under fruit cultivation is fluctuating over the years. It has been noticed that if there is increase in area there is increase in production. Sometime area does not affect the production due to fertility of the lands and 
use of fertilizers (both organic and chemical). Some time there is a huge pest problem which directly affect the quantity as well as the quality of the products. Overall growth trend of the fruit cultivation under the horticulture practices for both the area and the production is declined. This is due to the less demand of confined products. During the period of 2001-02, 2013-14 and 2017-18 the growth rate of area under fruits cultivation is negative and in 201718 it is -66.84 percent. Similarly, the growth rate of production of fruits in $2013-14$ ( -2.669 percent) and $2017-18$ (-85.81 percent) is negative.

Figure 1: Growth trend of area and production of Fruits

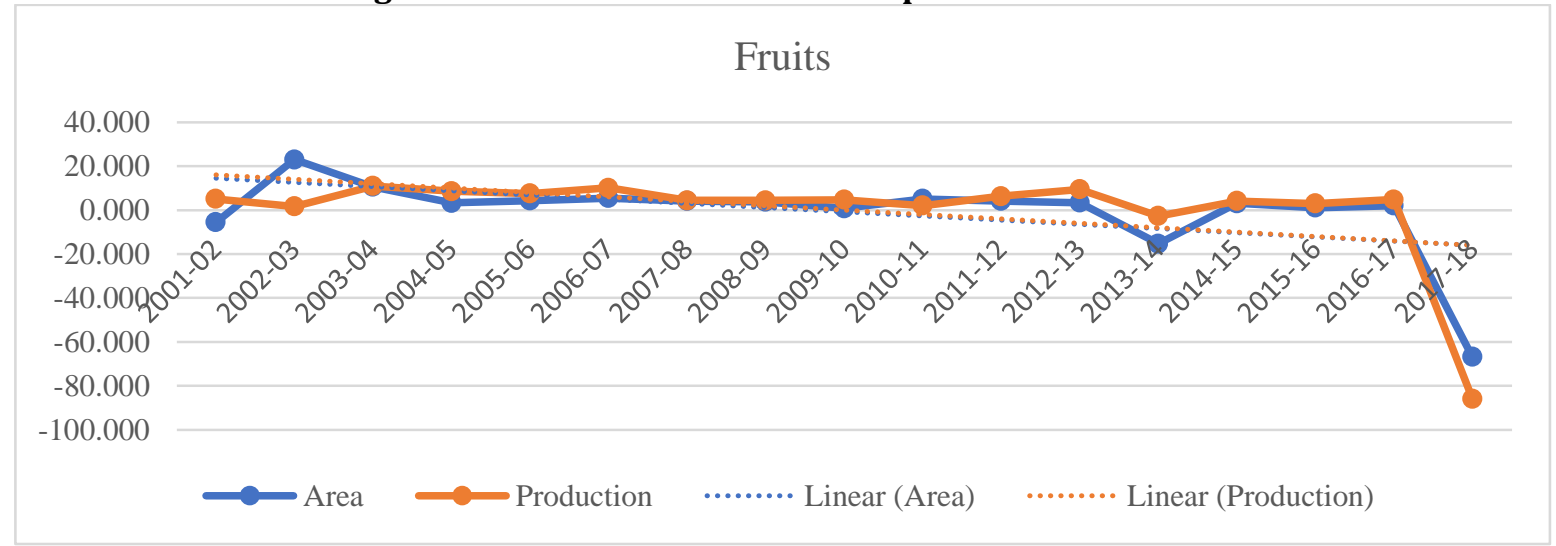

Likewise, the growth trend of vegetables crops under horticulture is fluctuating throughout the years. It is revealed that there is lack of scope and opportunities for the for the horticulture practices in India. From the Table 1 during the period 2017-18 the growth rate is above the 90 percent with negative sign. It implies farmers are not interested to adopt the practices as there may be huge risk factors like, market conditions, storage facilities, demotion of export of confined products as there is a huge competition of quality products.

Figure 2: Growth trend of area and production of Vegetables

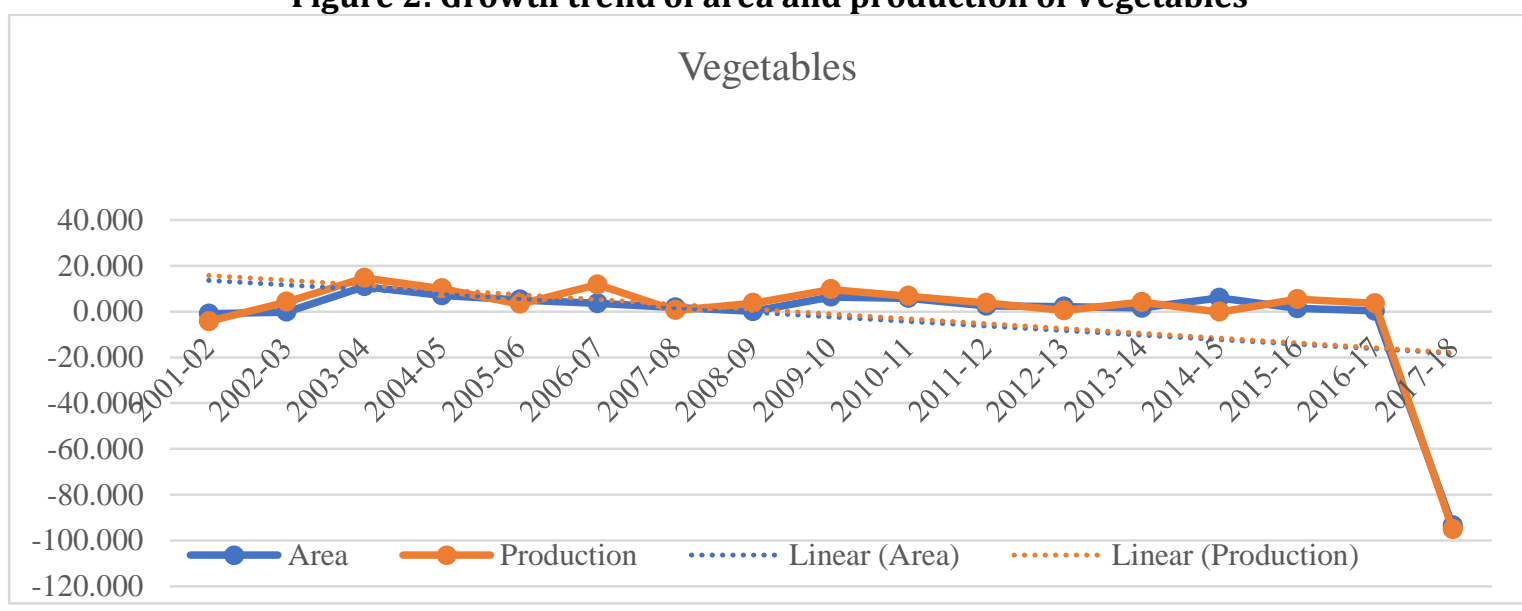


Figure 3: Growth trend of area and production of Flowers, Aromatic \& Medicinal plants

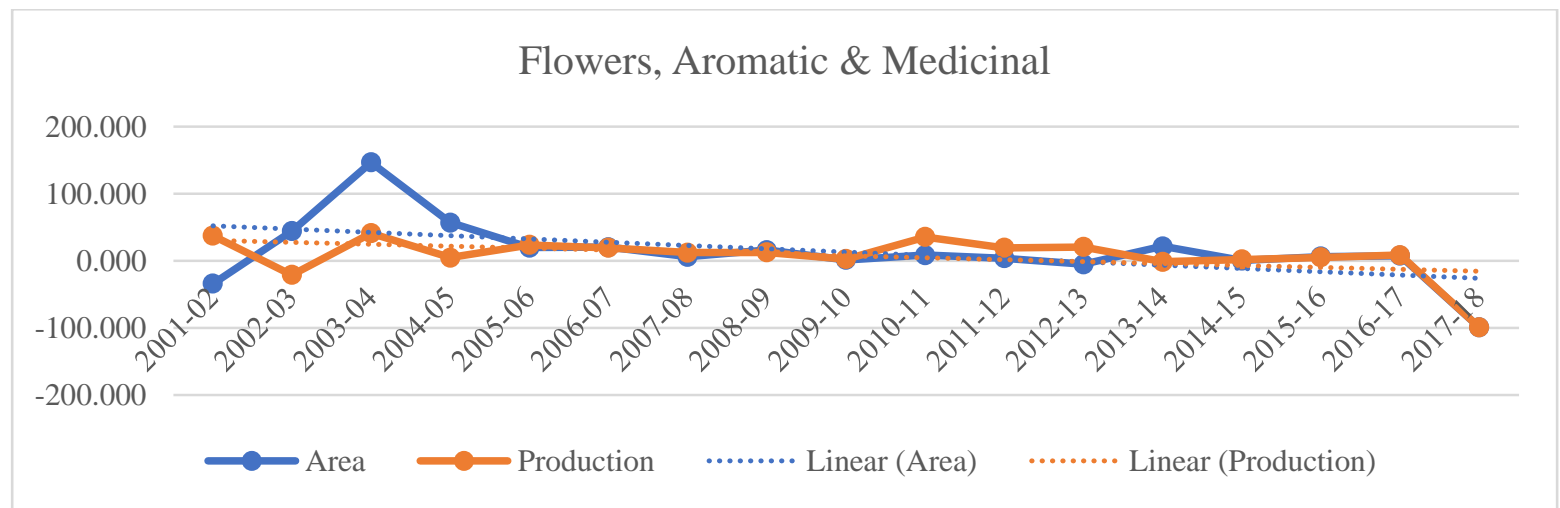

It has been observed that have seen there is a positive sight to encourage the production of flowers. It is peak with 146. 53 percent in 2003-04. The government has initiated different policies to encourage the farmers to produce more flowers and spread the floriculture enterprises. But there was some lacuna located in case of business. In bossiness purpose there are some draw backs found where neither the businessman nor the farmers get benefits which discourage the business personal as well as farmers' interest and as result there is negative trend during the period 2017-18. Though in India floriculture plays an important part of horticulture to grow the agriculture sector but in reality, there are a bunch of problems owing to the market imperfection and weak policy axioms. The insufficiency of new dynamic marketing strategies discourages the Indian farmers to market their yields.

\section{Figure 4 Growth trend of area and production of plantation crops}

\section{Plantation Crops}

\subsection{0}

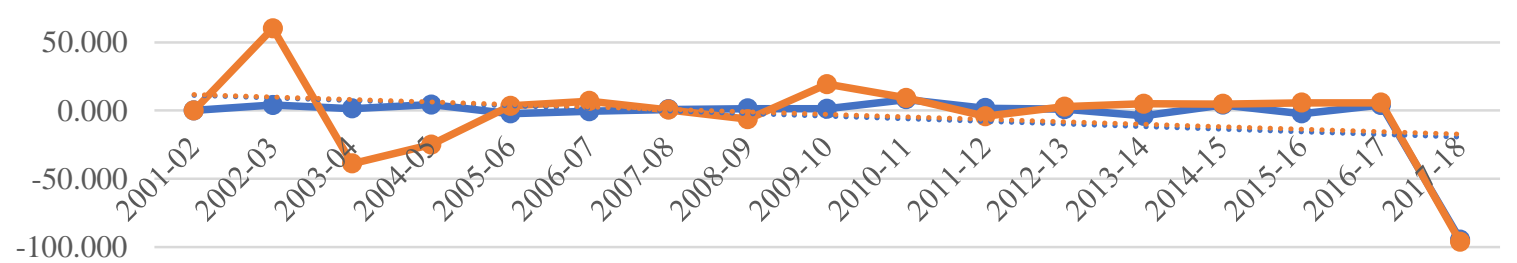

$-150.000$

$\longrightarrow$ Area $\longrightarrow$ Production $\quad$ ….... Linear (Area) ….... Linear (Production)


Figure 5: Growth trend of area and production of Spices

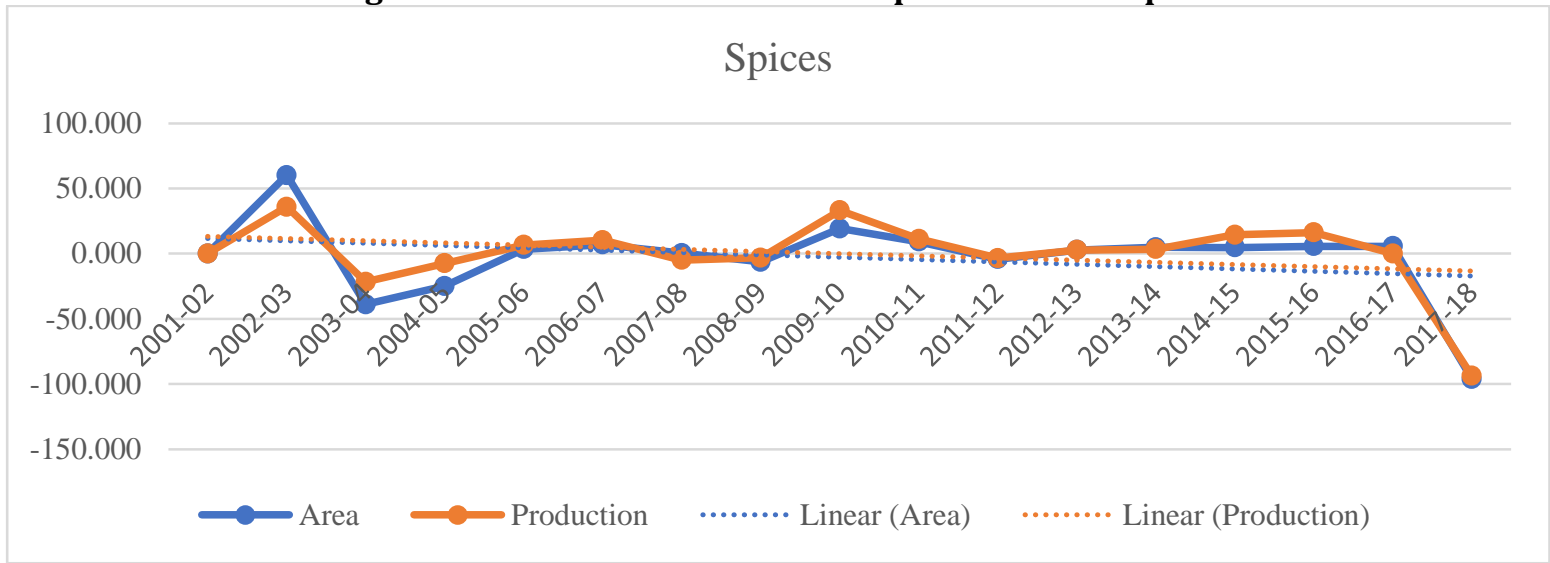

Figure 6: Growth trend of total area and production

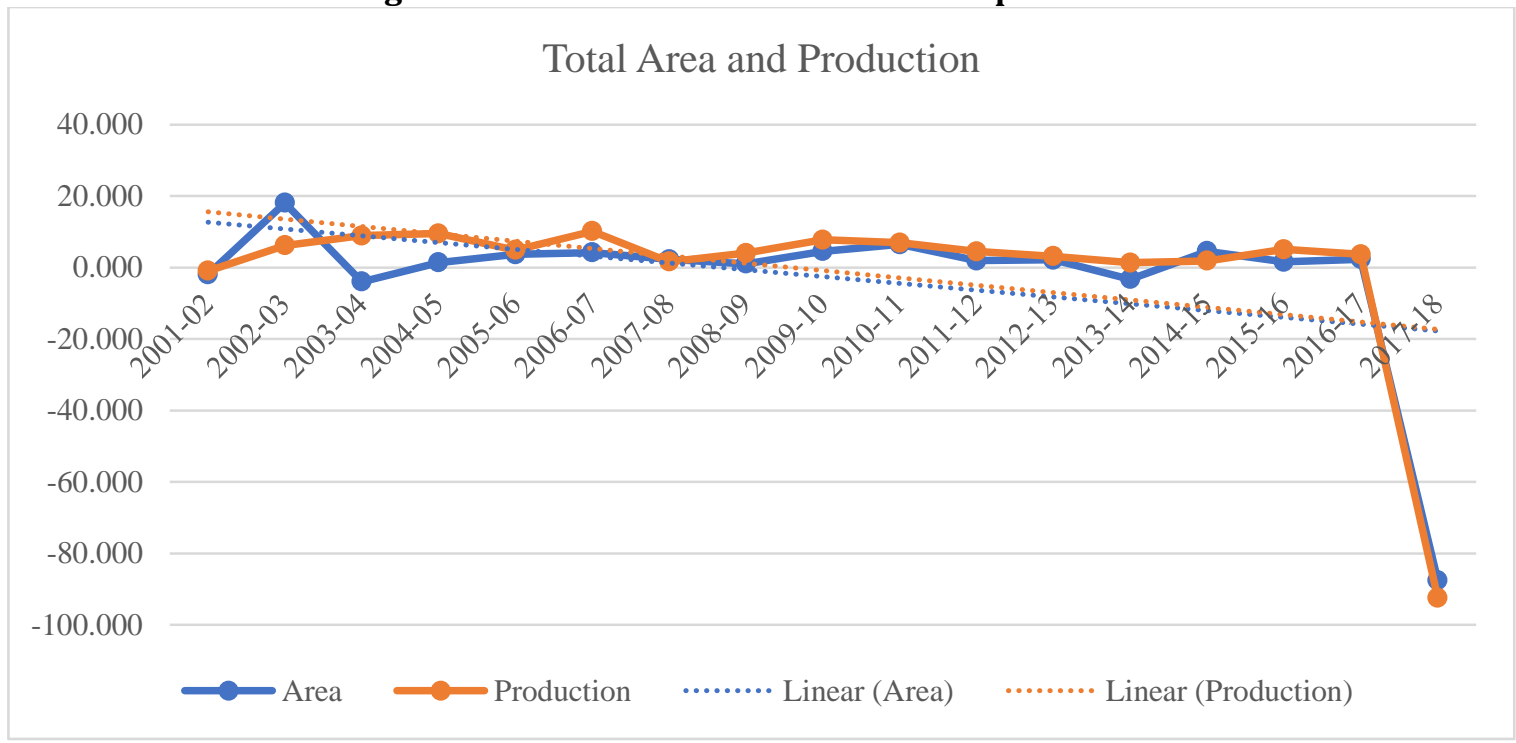

Overall growth of fruits, vegetables, flowers, plantation crops, spices are in declining trend. So, there is effective policy implication is required upliftment of the horticulture practices. As the horticulture practice is one of the dynamic sectors for the rural livelihood, it is important to enhance, mobilize and to reshape to enlarge the rural economy. 


\title{
SJIF Impact Factor 2021: 8.013| ISI I.F.Value:1.241| Journal DOI: 10.36713/epra2016 ISSN: 2455-7838(Online) EPRA International Journal of Research and Development (IJRD)
}

\author{
Volume: 6 | Issue: 5 | May 2021
}

- Peer Reviewed Journal

Table 2: Percentage share of different horticulture crops in India during 2001-02 to 2018-19

\begin{tabular}{|c|c|c|c|c|c|c|c|c|c|c|}
\hline Year & $\begin{array}{l}\text { Area of } \\
\text { fruits }\end{array}$ & $\begin{array}{l}\text { Production } \\
\text { of fruits }\end{array}$ & $\begin{array}{c}\text { Area of } \\
\text { vegetables }\end{array}$ & $\begin{array}{c}\text { Production } \\
\text { of } \\
\text { vegetables }\end{array}$ & $\begin{array}{c}\text { Area of } \\
\text { flowers, } \\
\text { aromatic } \\
\& \\
\text { medicinal } \\
\end{array}$ & $\begin{array}{c}\text { Production } \\
\text { of flowers, } \\
\text { aromatic \& } \\
\text { medicinal }\end{array}$ & $\begin{array}{c}\text { Area of } \\
\text { plantation } \\
\text { crops }\end{array}$ & $\begin{array}{c}\text { Production } \\
\text { of } \\
\text { plantation } \\
\text { crops }\end{array}$ & $\begin{array}{c}\text { Area } \\
\text { of } \\
\text { spices }\end{array}$ & $\begin{array}{l}\text { Production } \\
\text { of spices }\end{array}$ \\
\hline 2001-02 & 24.168 & 29.496 & 37.102 & 60.790 & 0.639 & 0.367 & 17.985 & 6.652 & 19.407 & 2.583 \\
\hline 2002-03 & 23.282 & 31.308 & 37.443 & 58.744 & 0.430 & 0.509 & 18.341 & 6.716 & 19.791 & 2.608 \\
\hline 2003-04 & 24.266 & 29.968 & 31.664 & 57.621 & 0.526 & 0.378 & 16.150 & 8.585 & 26.838 & 3.335 \\
\hline 2004-05 & 27.948 & 30.543 & 36.563 & 60.649 & 1.350 & 0.490 & 17.062 & 5.891 & 17.078 & 2.397 \\
\hline 2005-06 & 28.460 & 30.280 & 38.558 & 60.935 & 2.090 & 0.468 & 17.544 & 6.161 & 12.648 & 2.027 \\
\hline 2006-07 & 28.645 & 31.053 & 39.099 & 59.951 & 2.414 & 0.552 & 16.540 & 6.260 & 12.626 & 2.061 \\
\hline 2007-08 & 28.985 & 31.049 & 38.838 & 60.809 & 2.786 & 0.598 & 15.787 & 5.349 & 12.951 & 2.063 \\
\hline 2008-09 & 29.528 & 31.887 & 38.626 & 60.115 & 2.889 & 0.660 & 15.570 & 5.280 & 12.724 & 1.930 \\
\hline 2009-10 & 30.317 & 32.028 & 38.250 & 59.895 & 3.315 & 0.713 & 15.640 & 5.342 & 11.803 & 1.799 \\
\hline 2010-11 & 29.246 & 31.130 & 38.923 & 60.929 & 3.212 & 0.680 & 15.148 & 4.992 & 13.471 & 2.224 \\
\hline 2011-12 & 28.847 & 29.705 & 38.674 & 60.761 & 3.270 & 0.862 & 15.390 & 6.359 & 13.819 & 2.313 \\
\hline $2012-13$ & 29.467 & 30.235 & 38.849 & 60.327 & 3.334 & 0.985 & 15.367 & 6.318 & 12.982 & 2.137 \\
\hline 2013-14 & 29.821 & 32.081 & 38.830 & 58.733 & 3.091 & 1.151 & 15.187 & 5.877 & 13.071 & 2.130 \\
\hline 2014-15 & 26.100 & 30.821 & 40.760 & 60.315 & 3.879 & 1.119 & 15.096 & 5.543 & 14.169 & 2.174 \\
\hline 2015-16 & 25.748 & 31.512 & 41.296 & 59.074 & 3.727 & 1.120 & 15.038 & 5.821 & 14.196 & 2.442 \\
\hline $2016-17$ & 25.645 & 30.906 & 41.198 & 59.264 & 3.903 & 1.119 & 14.478 & 5.978 & 14.772 & 2.702 \\
\hline 2017-18 & 25.583 & 31.233 & 40.341 & 59.155 & 4.105 & 1.171 & 14.722 & 5.801 & 15.249 & 2.606 \\
\hline 2018-19 & 146.799 & 58.985 & 20.746 & 38.168 & 0.209 & 0.106 & 6.253 & 0.565 & 4.672 & 2.176 \\
\hline
\end{tabular}

It is observed from the Table- 2 that the percentage of area under fruits cultivation is increased up to 2013-14 after that it has been started declining and it is 25.59 percent in 2017-18. In 201819 it has increased suddenly to 146.80 percent and accordingly production of fruits has also been increased to 58.98 percent from 31.23 percent from the previous year. This is due to the growing market demand of fruits. People also prefer to have quality of products and as horticulture is one of the best agriculture practices for fruits with scientific technique to improve the quality of food. During the period of 2001-02 the level of production was very low with 29.50 percent.

In case of vegetables, it is quite different. From the Table- 2 it is evocated that the percent share of area and production of vegetable under horticulture cropping practices is stable during the period of 2001-02 to 2017-18 with close to 40 percent and 60 percent respectively. But in 2018-19 the total area has declined to 20.75 percent under vegetable cultivation which is half of the previous years. Similarly, the production in 2018-19 is also declined to 38 percent. This is due to the poor market condition and the adverse climate impact which directly affect the agriculture sector. Sometimes price of the product affects the horticulture as well as the agriculture practices. Increase in price embolden the framers and vice-versa. Similarly, in case of flowers, aromatic and medicinal plants the area as well as the production is also been decayed. The percentage share of area and the quantity is not even cross the 5 percent over the years. It is very heart throbbing for those are adopting horticulture practices. There is lack of motivations, scope for the products which demote the farmers.

Unlikely, for the plantation crops there is no remarkable increment. The area under plantation crops started falling from 2002-03 and reached it 18.34 percent to 6.25 percent in 2018-19. Similarly, the percentage share of production of plantation crops is also declined to 0.57 percent in 2018-19 from 8. 58 percent in 2003-04. In 2003-04 the production of plantation crops was maximum at it was new to the market people were encouraged for the newly emerged products. But gradually due to the market competition and failure in allocation of the products and a $\mathrm{s}$ a result the dynamic scenario of plantation crops is declined. It is also been revealed that in between the period 2001-02 to 2017-18 the production was stable which affect the dynamism of demand of the product and as an outcome there is a 


\section{SJIF Impact Factor 2021: 8.013| ISI I.F.Value:1.241| Journal DOI: 10.36713/epra2016 ISSN: 2455-7838(Online) EPRA International Journal of Research and Development (IJRD)}

sudden decline of the production process of the plantation crops. It is spotted that the percentage share of area and production of spices is under horticulture practices is deteriorated to 4.68 and 2.18 percent respectively from the 15.25 and 2.60 percent respectively in 2018-19 from the period 2017-18. In 2001-02 the percentage share of both area and the production of spices was quite noteworthy with 19.40 percent and 2.583 percent respectively. It is observed that the area and production are increased accordingly. It implies when area increases according production of the crops also increase and vice-versa.

\section{INTER-STATE VARIATION IN GROWTH RATE OF HORTICULTURAL PRODUCTION FROM 2008 TO 2018}

The growth rate of horticulture production has wide variation across the states in India. In 200809 , the growth rate is observed to be better in north eastern hilly states, particularly Mizoram, Sikkim and Assam because hilly lands and their climatic conditions are suitable for horticultural crops. The statewise percentage growth rate from 2008-09 to 2017-18 is shown in Table-3. The average growth rate in $2010-11$ is 17.52 per cent whereas it is only 1.02 per cent in 2017-18. There is declining trend of growth rate during the period of study. The coefficient of variation in growth rate is highest in 2015-16 and lowest in 2008-09. Since the coefficient of variation is above 100 in all the years, it implies significant variation in horticulture production across the states in India.

Table 3: State wise growth percentage of horticulture Production in India

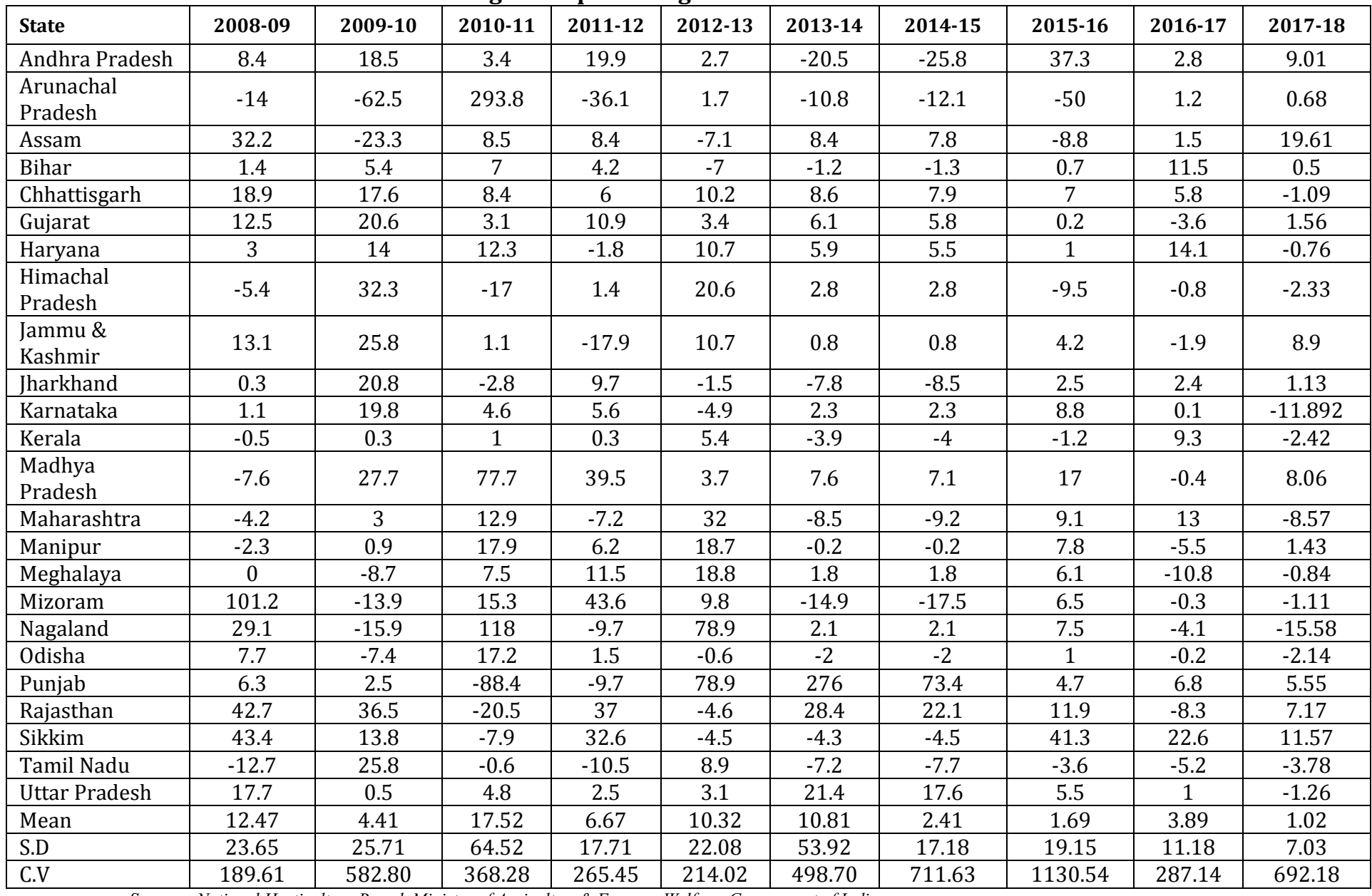




\section{HORTICULTURE IN ODISHA}

Odisha produces about 10.30 million tons of horticulture products from an area of 1.21Million hectors and accounts for 4.28 percent of the total horticultural production of the country. The agroclimatic conditions are immensely suitable for perennial fruit crops like mango, litchi, guava, Oranges, and lime annual fruit crops like banana, pineapple, and papaya spices like ginger, turmeric, and chilly variety of roots and tuber and a whole range of vegetables. Odisha ranks $2^{\text {nd }}$ position as per production of vegetables at the national level. The per capita consumption of vegetables is highest in the country. Over the years, horticulture has emerged as one of the most potential agricultural enterprises in accelerating the growth of the economy. There are many reasons to develop horticulture in the rural area of Odisha. Due to the rising domestic demand for horticulture commodities, driven by rising incomes, urbanization, and perhaps changing preferences. On the other, trade liberalization has opened export markets in other countries where high-income consumers demand fruits, vegetables, and spices which have put a lot of demand for horticultural products. And finally, market reforms have allowed more foreign direct investment in developing countries, introducing more competition in food processing and retailing sectors, as well as allowing foreign companies to organize production for export. Under NHM Odisha performed well and a National level winner. It includes planting material production to post-harvest management. Horticulture can provide better livelihood along with much better income opportunity. A positive growth trend was seen in the production of fruit and vegetable from 18$23 \%$ to $10-20 \%$ during $1993-94$ to $2011-12$ the share of horticulture sector accounts near about $37 \%$ of total agricultural commodity exported. The production trend shows $5.3 \%$ per year growth rate between 2001-02 to 2016-17.

The comparative growth trend between India and Odisha has been shown in Table- 4.

Table 4: Comparison of growth percentage of horticulture production between Odisha and India

\begin{tabular}{|c|c|c|c|c|c|c|c|c|c|c|c|c|c|c|c|}
\hline Year & $\begin{array}{c}2003- \\
04\end{array}$ & $\begin{array}{c}2004- \\
05\end{array}$ & $\begin{array}{c}2005- \\
06\end{array}$ & $\begin{array}{c}\text { 2006- } \\
07\end{array}$ & $\begin{array}{c}2007- \\
08\end{array}$ & $\begin{array}{c}2008- \\
09\end{array}$ & $\begin{array}{c}2009- \\
10\end{array}$ & $\begin{array}{c}2010- \\
11\end{array}$ & $\begin{array}{c}2011- \\
12\end{array}$ & $\begin{array}{c}2012- \\
13\end{array}$ & $\begin{array}{c}2013- \\
14\end{array}$ & $\begin{array}{c}\text { 2014- } \\
15\end{array}$ & $\begin{array}{c}2015- \\
16\end{array}$ & $\begin{array}{c}2016- \\
17\end{array}$ & $\begin{array}{c}2017- \\
18\end{array}$ \\
\hline Odisha & 0.8 & -0.6 & 1.4 & -1 & 3.5 & 7.7 & -7.4 & 17.2 & 1.5 & -0.6 & -2 & -2 & 1 & -0.2 & -2.14 \\
\hline India & 7.6 & -0.72 & 13.78 & 10.11 & 1.32 & 3.84 & 8.19 & 6.02 & 5.43 & 3.09 & -0.82 & 4.16 & 5.05 & 3.68 & 0.69 \\
\hline
\end{tabular}

It is seen that the overall growth trend is declining over the year. In Odisha the during the period of 2009-10 it is negative with -7.4 percent. This might be due to the inattention of market policy for the horticultural products which push back the farmers not to produce more. Also due to the storage facilities, export promotions measures discourage the horticulture practices. On the other hand, to over come the negative growth pattern various incentives have been taken and as a result there is a sudden growth of overall horticulture productivity during 2010-11 with 17.2 percent. One peculiar thing has been observed from the period of 2003-04 to 2012-13 the trend is opposite to each other between India and Odisha. When the growth trend of Odisha has increased the growth trend of India has declined and vice versa. After 2012-13 the trend of India and Odisha has fluctuated.

Figure 7: Comparison of growth percentage of horticulture production between Odisha and India

\section{Comparison of growth percentage of horticulture production between} Odisha and India

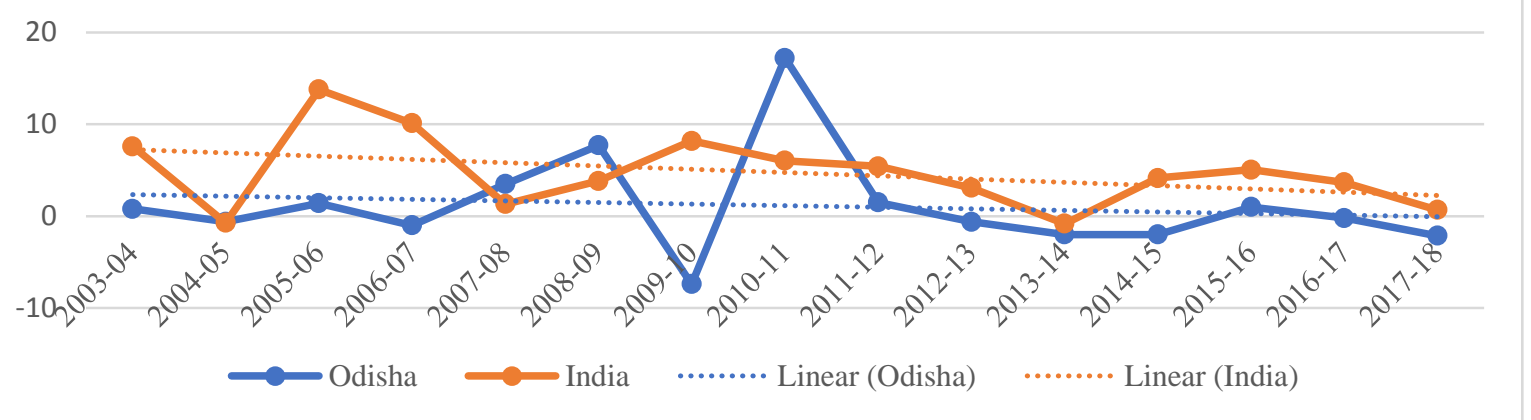




\section{SJIF Impact Factor 2021: 8.013| ISI I.F.Value:1.241| Journal DOI: 10.36713/epra2016 ISSN: 2455-7838(Online) EPRA International Journal of Research and Development (IJRD)}

\section{SUGGESTIONS AND CONCLUSION}

From the above analysis it is revealed that there are many lacunas for the growth of horticulture practices. Horticulture plays an important role for rural livelihood as it has the great impact on rural employment Enforcement of Government scheme to enhance the horticulture practices. As still there is a problem of food security there is a need to circulate food security chain to curb the problems like starvation and nutrition. It is clearly outlined from the study that horticulture sector is suffering from various issues like market structure, technical, economical as well as geographical discrepancies. To recovery from these sorts of maladies and to make agriculture as well as horticulture sector grass root level research-based approaches should be undertaken by the government. The suggestions for improvement of Horticulture are state below.

(i) To solve the spatial discrepancies between inter and intra-states the barebones such as technology, crop varieties, augmenting credit delivery, specification of region and plans for specification crops and approaches should be implemented to abate the unstable development in agriculture.

(ii) To use new technology, knowledge of time operation and they suggest to improve more field mechanism for more benefit through more research.

(iii) Education level of the farmers needs to be improved. As we know diffusion of innovation is an important medium to channelize the new idea and knowledge and to create awareness about the new strategies. The short messaging service (SMS) through mobile phones has a crucial role circulate and to aware the people about new knowledge. But it is significant to say that except education there no value of new idea and new knowledge.

(iv) To implement by the government and to adoption capacity of the farmers depend on their own education and skill. Notwithstanding the cost usefulness, mobile messaging has persisted a hindrance of the end users in the farming sector. As it is observed the only and ultimate factor that influences to adopt extension services is the education level of the farmers or the users. The factors like irrigation facility, market condition of the horticultural products, promotion of the crops, storage facility of the crops, training of the farmers and environmental factors such as climate and geographical characteristics such as quality of soil and ground water table influence the horticulture practices as well as other agriculture productivity and export of the products.

(v) The environmental factors such as climate and geographical characteristics such as quality of soil and ground water table influence the horticulture as well as other agriculture productivity and export. To increase the horticulture export and ultimately achieve sustainability the role institutions is very crucial. The institutions like The Agricultural and Processed Food Products Export Development Authority (APEDA), International Standard Organization (ISO) to assure and quality control, National Cooperative Development Cooperation (NCDC) etc. play a pivotal role to accelerate the export as well as productivity. Export of Horticultural yields depend on dynamics like domestic production and ingestion, exportable excesses, consumer prejudices, varieties merchandized, quality, domestic and international prices and accessibility of infrastructure facilities for storage and postharvest management.

(vi) Various government initiative and projects are moving the interest of people from traditional grains cultivation towards horticulture produce. He analyses how government projects in Nepal doing well apart from its geographical location. Large cardamom, tea, coffee are the leading products which give a push to trade -off with other countries. These cash crops are beneficiated the farmers and differ reward of government push the interest of people towards the cash crops.

(vii) It would be better if the farmers adopt proper knowledge, suitable technologies and financial assistance to curtail the risks. The authors have also been stated that to get the better effect for the post-harvest issues farmers' organization can be formed at the cluster level to link with the market and training should be provide by emphasizing the approaches of the market.

(viii) To make agriculture sustained the techniques like conservation agriculture, use of renewable energy, forest and water conservation should be followed in the horticulture practices.

(ix) To adopt and implement better irrigation facilities to the rural small and marginal farmers so as to utilize all their barren land to increase their productivity and can boost 
their livelihood during the climate change specially shortage of rainfall.

Many evidences reveal that climate change has already affected horticultural production. Horticulture production affected by causes related with a biopic stresses and biotic stresses. For profitable commercial product and satisfying demand of product hi-tech horticulture practice taken into account. Precision farming are more popular among the farmers. Moreover, awareness, skill and quality control strategies depreciate the turnover and so as the farmers in India. It is observed that the tribal as well as other farmers also growing turmeric with traditional method that would be the cause of deteriorate the yield. Land preparation and postharvesting matters are other characteristics to increase the productivity but as the tribal people are far away from the mainstream of the cotemporary world, they are inept to adopt the new and effective strategies to enhance their productivity. The introduction and standardization of high density planting in key fruits can ensure optimum utilization of land, light and nutrients resulting good harvest of horticultural crops. Good horticultural practices, integrated production and pest management and organic farming can lead to sustainable and environmentally friendly horticultural crops.

\section{REFERENCES}

1. Babu, N., Shukla, A.K., Tripathi, P.C. \& Prusty, M. (2015). Traditional Cultivation Practices of Turmeric in Tribal Belt of Odisha. Journal of Engineering Computers \& Applied Sciences (JECAS) 4(2), pp.52-57.

2. Bader, B. R., Abood, M. A., Aldulaimy, S. E. H., Al-Mehmdya, S. M. H., \& Hamdi, G. J. (2020). Effect of water deficit and foliar application of amino acids on growth and yield of eggplant irrigated by two drip systems under greenhouse conditions.

3. Bhan, S. \& Behera, U. K. (2014). Conservation agriculture in India - Problems, prospects and policy issues. International Soil and Water Conservation Research, 2(4), pp. 1-12.

4. Birthal, P. S., Joshi, P.K., Chauhan, S. \& Singh, H. (2008). Can Horticulture Revitalise Agricultural Growth? Indian Journal of Agriculture Economics, 63(3), pp. 310-321.

5. Datta, S. (2013). Impact of Climate Change in Indian Horticulture - A Review. International Journal of Science, Environment and Technology, 2(4), pp. 661-671.

6. Gowda, M.J.C. \& Dixit, S. (2015). Influence of farmers' educational level on comprehending, acting-upon and sharing of agro advisories. Journal of Agriculture and Rural Development in the Tropics and Subtropics, 116(2), pp. 167-172.

7. Meena, M.S., Kumar, A., Singh, K.M. \& Meena, H.R. (2009). Farmers' Attitude Towards Post-
Harvest Issues of Horticultural Crops. Indian Research Journal of Extension Education, 9 (3), pp.15-19.

8. Mittal, S., (2007). Strengthening Backward and Forward Linkages in Horticulture: some successful initiative. Agricultural Economics Research Review.pp.457-469.

9. Patra, R. (2014). Agricultural development in Odisha: Are the Disparities Growing? International Journal of Food and Agricultural Economics, 2(3), pp. 129-144.

10. Sahoo, P.P., Sarangi, K.K., Sangeetha, M., Shasani, S. \& Saik, N.H. (2018). SWOT Analysis of Agriculture in Kandhamal District of Orissa, India. International Journal of Current Microbiology and Applied Sciences, 7(8), pp. 1592-1597.

11. Singh, A. (2018). Assessment of different strategies for managing the water resources problems of irrigated agriculture. Agricultural Water Management, 208, pp. 187-192. 